\title{
Article \\ A Ćuk Converter Cell Balancing Technique by Using Coupled Inductors for Lithium-Based Batteries
}

\author{
Ali Farzan Moghaddam * and Alex Van den Bossche \\ Department of Electrical Energy, Metals, Mechanical Constructions and Systems, Gent University, \\ 9052 Gent, Belgium \\ * Correspondence: ali.farzanmoghaddam@ugent.be
}

Received: 27 June 2019; Accepted: 23 July 2019; Published: 26 July 2019

check for updates

\begin{abstract}
In this paper, a ćuk converter balancing method by using a coupled inductor for lithium based batteries is investigated. The proposed circuit is an active balancing circuit that will equalize eight battery cells in a series. In electrical vehicles (EV), a battery management system (BMS) is a vital task to achieve the best performance of the batteries and longer lifetime. The problem of voltage difference in a battery pack is an important issue to be improved. To overcome the voltage differences in battery string, an equalizing method is mandatory. The conventional cuk converter requires $2(n-1)$ switches to balance $n$ cells, while the proposed circuit requires only $n$ switches for $\mathrm{n}$ cells in series. In addition, the proposed developed topology uses coupled inductors instead of un-coupled inductors, unlike the traditional ćuk converter balancing method. Since the ćuk balancing transfers the energy among two adjacent cells, it requires a proportionately long equalization time particularly for long string battery packs, but the coupled inductor ćuk converter type overcomes this problem. The switches are N-channel metal-oxide field-effect transistor (MOSFET) to achieve lower drain-source on-resistance, $\mathrm{R}_{D S(o n)}$, and less voltage drop as compared to the P-channels. The switches are triggered by complementary signals. The coupled inductor is made in such a way to hold the same magnetizing inductance. It can be done by using five wires in one hand. The circuit contains five inductors, one magnetic core, with five winding for eight cells, and one capacitor for two cells. Therefore, the overall circuitry and complexity of the circuit are reduced, resulting in a more cost-effective and easy to implement circuit. The system also does not demand complicated control for battery equalizing. The experimental circuit was implemented and simulation results were obtained to confirm the validity of the proposed system.
\end{abstract}

Keywords: BMS; ćuk converter; coupled inductors; EV; li-ion; MOSFET

\section{Introduction}

Electric vehicles can attain low contamination and low noise associated with traditional gasoline-powered transportation, thus the peremptory request for electric vehicles is increasing during the last decades [1]. In addition, the world is facing some challenges such as global warming, air pollution and depletion of fossil fuels, therefore electric vehicles will have a significant role in transportation in the future. The biggest expense in EVs is the cost of the batteries, thus a battery management system is required to achieve the best performance. Lately, lithium batteries are broadly used in many applications and they are the most common energy storage devices as substitution of standard fuel [2]. They are broadly used for several purposes such as uninterruptible power supply (UPS), electric bike, electric scooter, and hybrid electric vehicles (HEV) [3]. These usages may employ hundreds of cells in parallel or series to achieve high voltage and capacity for the desired applications because the open-circuit voltage of the battery is low [4]. They have some benefits such as low self-discharge rate, lower weight, high density, and no memory effect $[5,6]$. 
In lithium based batteries, voltage variations exist within cells due to the charging/discharging process. Furthermore, manufacturing technology cannot guarantee equal cell output voltages, resulting in cell imbalances. These inescapable unbalanced cells are because of electrical and chemical characteristics, asymmetrical degeneration with aging, production tolerance, inner impedance, and unequal temperature $[7,8]$. The imbalances decrease the lifetime of the battery as well as reduce the charge potential, and they are the main factor to degenerate the performance of the battery pack. The capacity of the battery is also reduced due to temperature and passivation and this problem increases with cell aging [9].

To improve these imbalances, a BMS is introduced to ensure all cells are equally fully charged. It monitors battery modules, provides protection and plays an important role in electrical vehicles. It has some features, for instance, it detects battery charge, battery voltage, battery temperature, discharge current, and it has over-voltage, under-voltage, and short circuit protection. Several cell equalization techniques are introduced in the last decades. These balancing methods are principally separated into two categories, active and passive balancing methods [10-15].

The passive balancing methods connect resistors in parallel to individual battery cells. The extra energy dissipates as heat. It is based on removing energy from the higher cell by bypassing the current of the highest cells until the charge equals those of the lower cells in the pack. This method is split into two types: fixed shunt resistors [16] and switched shunt resistors balancing [17]. The advantages of the resistor balancing method are low cost and easy implementation, while the requirement for high power resistor, energy dissipation, and low efficiency are its disadvantages. The switched resistor balancing is shown in Figure 1. To solve the problem of energy losses, active equalizing methods are introduced. They equalize the battery cells by transporting the energy from higher cells to the lower ones and they are split into many types such as switches capacitor, inductor, and transformer balancing methods.

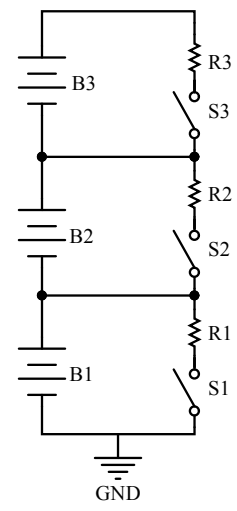

Figure 1. Switched shunt resistor balancing method.

The switched capacitor converter (SCC) balancing method is an active equalizing technique that uses capacitors as an energy storage device for transferring charge between the cells. There are many types of capacitor balancing such as a single switched capacitor, a double-tiered capacitor, and a resonant switched capacitor. The switched capacitor has two operation modes, charging and discharging. The capacitors are used to transfer charge between the cells. A simpler circuitry is its advantage, while long equalization time is its disadvantage [18,19]. A switched capacitor balancing circuit is presented in Figure 2. The double-tiered capacitor requires two capacitors for energy transferring and the advantage is reduced balancing time [20]. However, the resonant switched capacitor balancing has a lower equalizing time [10]. 


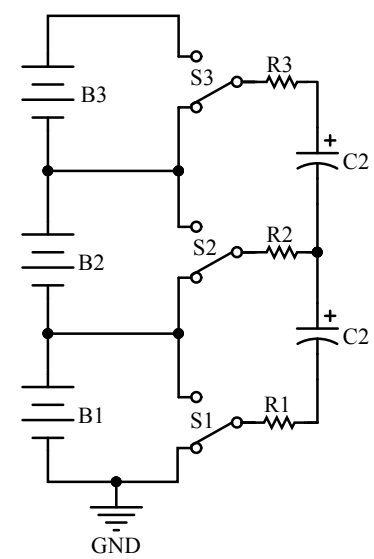

Figure 2. Switched capacitor converter balancing method.

The inductor balancing technique transfers energy between cells by using inductors and has fast equalization time as compared witch capacitor balancing [11], but a high cost and magnetic losses are its disadvantages. The conventional inductor balancing has longer balancing time as compared to the transformer balancing because of energy transfer from cell to cell [21-23]. The coupled inductor balancing has a lower cost because it uses one magnetic core and it has fast balancing time [13].

The transformer balancing technique has a smaller equalizing time compared to other methods $[12,15]$. The multi winding transformer has a magnetic core with one primary and multiple secondaries for every cell, as shown in Figure 3. The advantages of transformer balancing circuits are fast balancing time, direct energy transfer is possible between non-neighboring cells and easy to control [24]. However, the secondary winding voltages are not equal due to the nonuniform turn ratio of secondary winding leakage inductance, and also magnetic losses and high cost are its disadvantages [25-27].

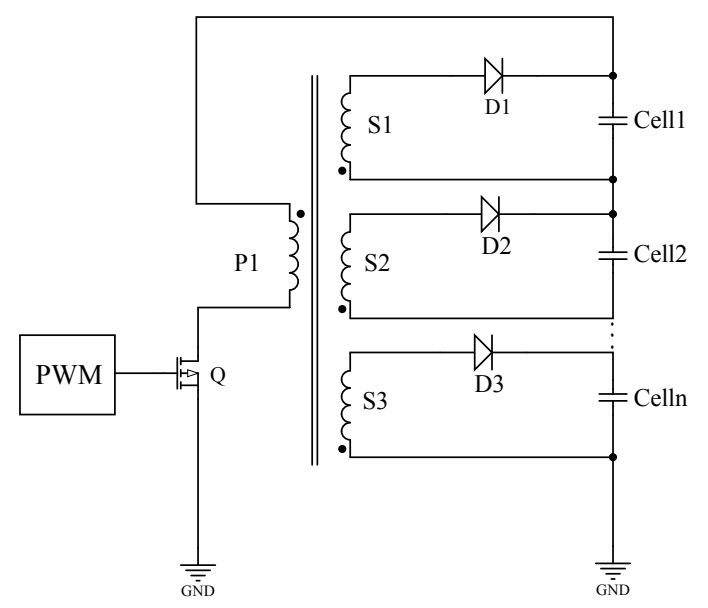

Figure 3. Multi winding transformer balancing method.

\section{The Conventional Ćuk Converter Balancing Technique}

The conventional ćuk converter balancing circuit is shown in Figure 4. The ćuk converter has non-dissipative currents, a bidirectional energy transferring capacity, and high efficiency [14,28-30]. The conventional ćuk converter requires $2(n-1)$ switches, and $n-1$ capacitors in order to balance $\mathrm{n}$ number of battery cells [30]. The operational principle is divided into two stages, Firstly, switches Q1, Q3, and Q5 are turned on, while the other switches are turned off. In the next stage, switches Q2, Q4, and Q6 are turned on while the other switches are turned off. This circuit equalizes four cells in a battery string connected in series. 
To investigate the difference between conventional and the proposed ćuk converter balancing circuit, the two circuits with four cells were simulated with MATLAB software and the simulation results are presented. The operational principle was simplified with two cells to investigate the circuit.

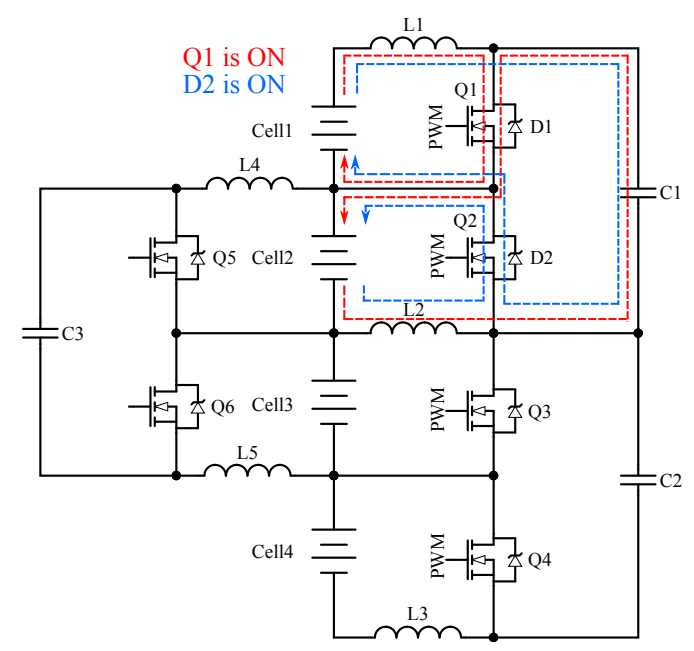

Figure 4. Conventional ćuk converter balancing circuit.

In the first mode, Q1 is turned on while Q2 is turned off; the cell voltage equations can be written as

$$
\begin{aligned}
& V_{\text {Cell 1 }}=L_{1} \frac{d i_{L_{1}}}{d t} \\
& V_{\text {Cell } 2}=-L_{2} \frac{d i_{L_{2}}}{d t}+V_{C_{1}}
\end{aligned}
$$

In the next mode, Q1 and Q5 are turned off and the body diode of Q2 is turned on; the cell voltage equations can be expressed as

$$
\begin{aligned}
& V_{\text {Cell 1 }}=L_{1} \frac{d i_{L_{1}}}{d t}+V_{C_{1}} \\
& V_{\text {Cell 2 }}=-L_{2} \frac{d i_{L_{2}}}{d t}
\end{aligned}
$$

By applying Volt-sec balance across $\mathrm{L}_{1}$ and $\mathrm{L}_{2}$,

$$
V_{\text {Cell } 1} D T+\left(V_{\text {Cell 1 }}-V_{C_{1}}\right)(1-D) T=0
$$

Similarly, Volt-sec balance across $\mathrm{L}_{1}$ and $\mathrm{L}_{2}$,

$$
\left(-V_{\text {Cell } 2}+V_{C_{1}}\right) D T+\left(-V_{\text {Cell } 2}\right)(1-D) T=0
$$

The expression for average inductor current can be obtained from charge balance of $C_{1}$ as

$$
i_{L 1}(1-D) T_{S}-i_{L 2} D T_{S}=0
$$

where $D$ is duty cycle and $T_{s}$ is switching frequency.

\section{The Simulation Result of the Conventional Cuk Converter Balancing Circuit}

The simulation results of the conventional cuk converter with MATLAB are presented in this section. The switches are N-channel MOSFETs with body diodes and they are triggered by pulse width 
modulation (PWM), created by a pulse generator with a synchronous pattern. The switching frequency is $50 \mathrm{kHz}$ with the duty ratio of $50 \%$. The batteries are modeled with the capacitors with the value of $0.5 \mathrm{~F}$. The inductors are $10 \mu \mathrm{H}$ and the capacitors are $100 \mu \mathrm{F}$.

In Figure 5a, the cell voltages of the conventional cuk balancing circuit after equalization is presented. It was found that it does not converge at the end. The inductor voltages in steady-state are shown in Figure 5b. It was observed that the inductor voltages are not at the same level of voltage. They should be at the same voltage, which means they are not equalized well.

Figure $5 c$,d shows the inductor currents and capacitor voltages, respectively. In Figure $5 c$, it can be noticed that the inductor currents are not at the same level, which means the cells are not balanced.

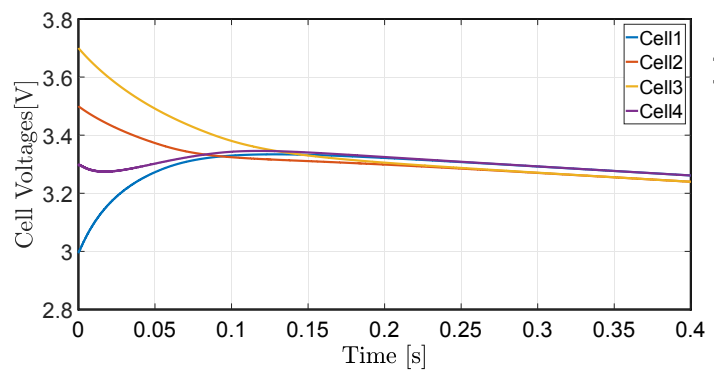

(a)

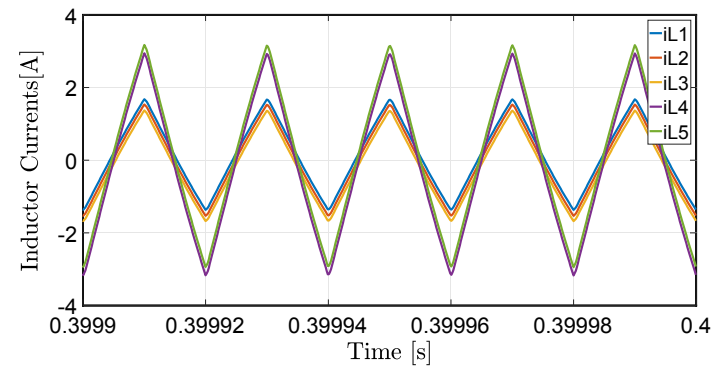

(c)

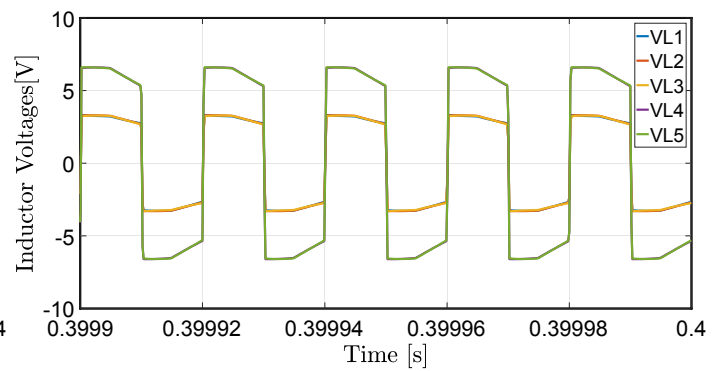

(b)

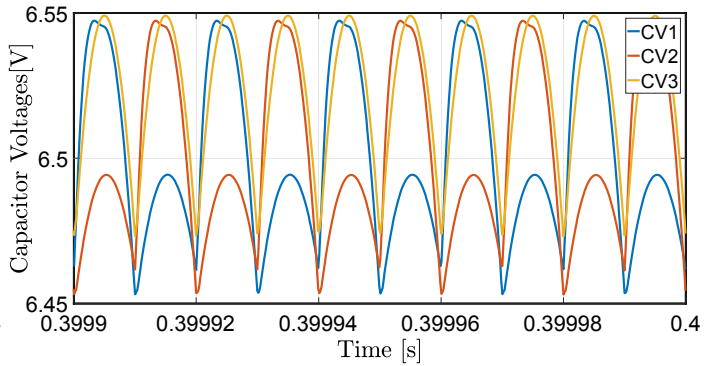

(d)

Figure 5. (a) Cell voltages of the conventional ćuk balancing circuit; (b) inductor voltages of the conventional ćuk balancing circuit in steady-state; (c) inductor currents of the conventional cuk balancing circuit in steady-state; and (d) capacitor voltages of the conventional cuk balancing circuit in steady-state.

To compare a conventional ćuk converter balancing method with a buck-boost converter balancing method, the buck-boost converter balancing circuit with four battery cells was investigated. In Figure 6, the buck-boost circuit is shown. The buck-boost converter balancing has too many switches, i.e., more than one switch per cell.

The circuit has two stages. In the first stage, Q1, Q3, and Q5 are turned on while the other switches are turned off. The energy is stored in the inductors $\mathrm{L}_{1}, \mathrm{~L}_{2}$, and $\mathrm{L}_{3}$ by Cell 1, Cell 2 and Cell 3.

In the next stage, the switches Q2, Q4, and Q6 are turned on while the other switches are turned off. In this stage, the stored energy in the inductors is transferred to Cell 2, Cell 3, and Cell 4.

The cell balancing simulation results of the buck-boost converter balancing circuit are presented in Figure 7. All components parameters are the same as the ćuk converter balancing method. It can be noticed that the balancing time is longer as compared to the cuk balancing circuit with coupled inductors, shown in the next section.

The simulation result of the inductor currents are presented in Figure 8a,b, respectively. It can be seen in Figure 8a that, in transient, the currents are not at the same level, but in steady state the current does converge. The blue waveform is corresponding to inductor $\mathrm{L}_{3}$. 


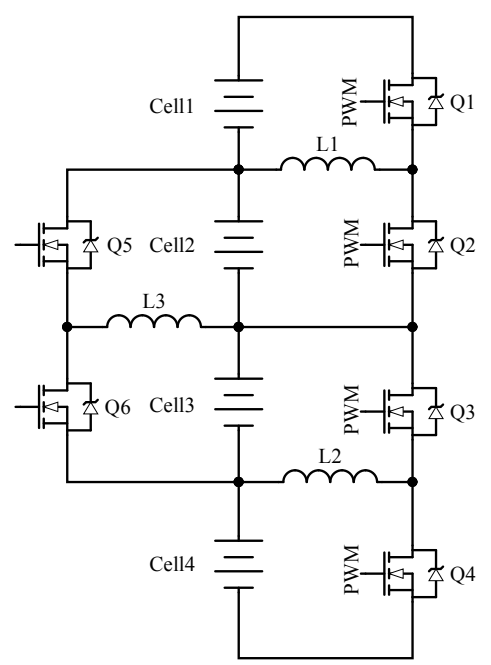

Figure 6. Buck-Boost converter balancing circuit.

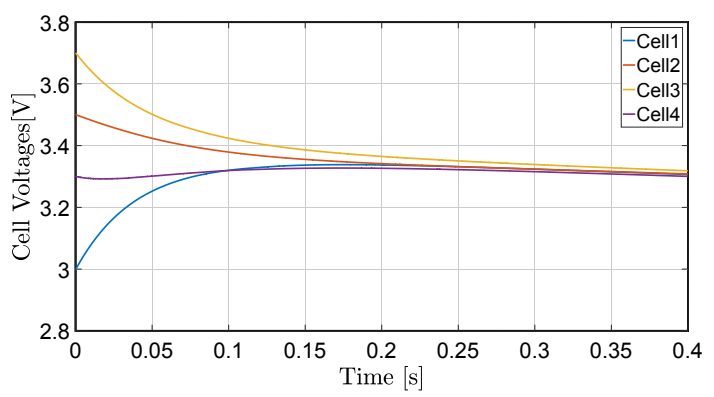

Figure 7. Cell voltage vs. time of the buck-boost balancing circuit.

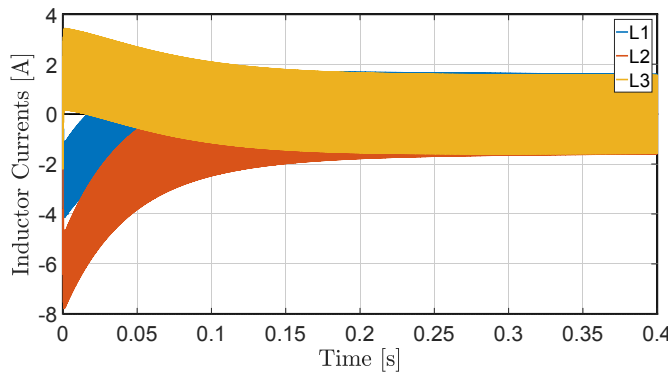

(a)

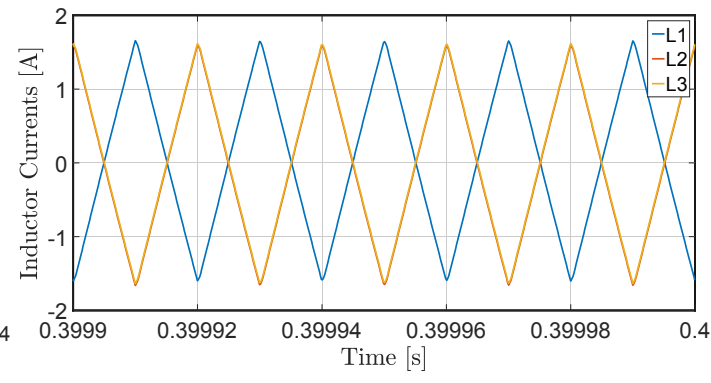

(b)

Figure 8. (a) Inductor currents of buck-boost balancing circuit in transient; and (b) inductor current of buck-boost balancing circuit in steady state.

\section{The Proposed Ćuk Converter Balancing Circuit}

The proposed cuk converter balancing circuit with coupled inductors was investigated. The schematic of the proposed circuit is shown in Figure 9. In some applications, a premiere performance can be achieved by magnetic devices and not by capacitors; in this circuit a coupled inductor is used instead of inductors. The circuit equalizes eight battery cells in series with one magnetic core and five coupled inductors.

The conventional ćuk converter requires $2(n-1)$ switch per $n$ cells, while the proposed circuit uses $n$ switches per $n$ cells. Furthermore, the conventional cuk circuit requires $n-1$ capacitors per $n$ cells, while the proposed circuit requires only $n$ capacitors per $2 n$ cells, thus the number of capacitors is reduced by a factor of two. 
The proposed ćuk converter balancing circuit with coupled inductors uses one magnetic core with five coupled inductors for eight cells. The inductors are made in such a way as to have the same leakage inductances. The operational principle can be split into two modes.

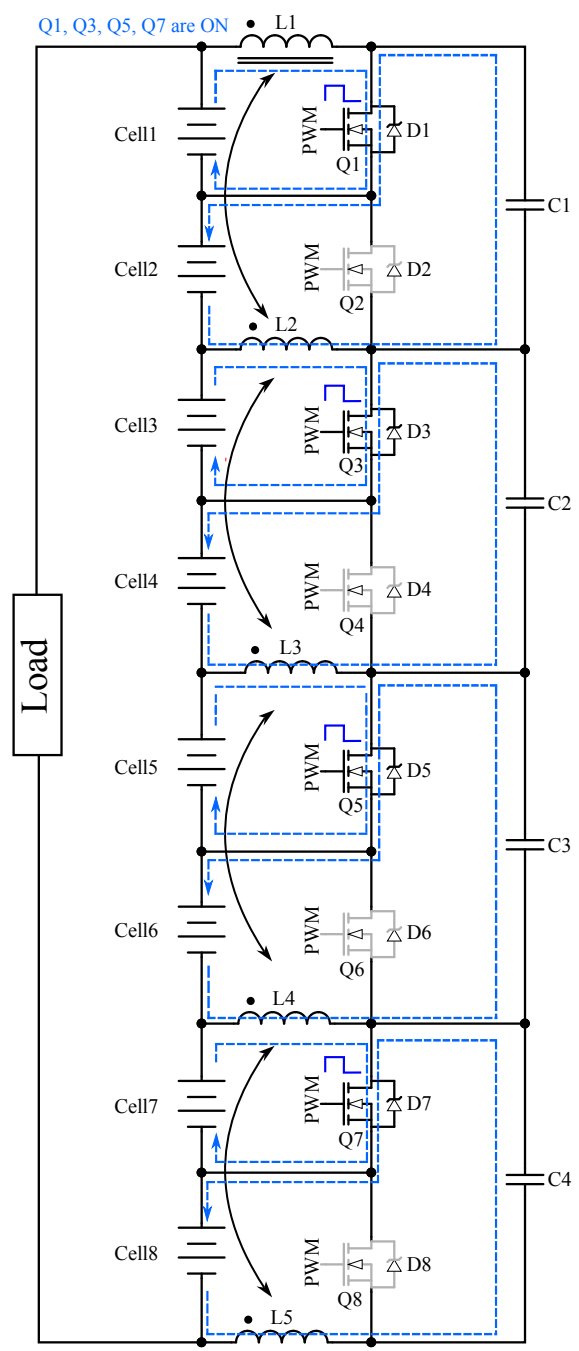

(a)

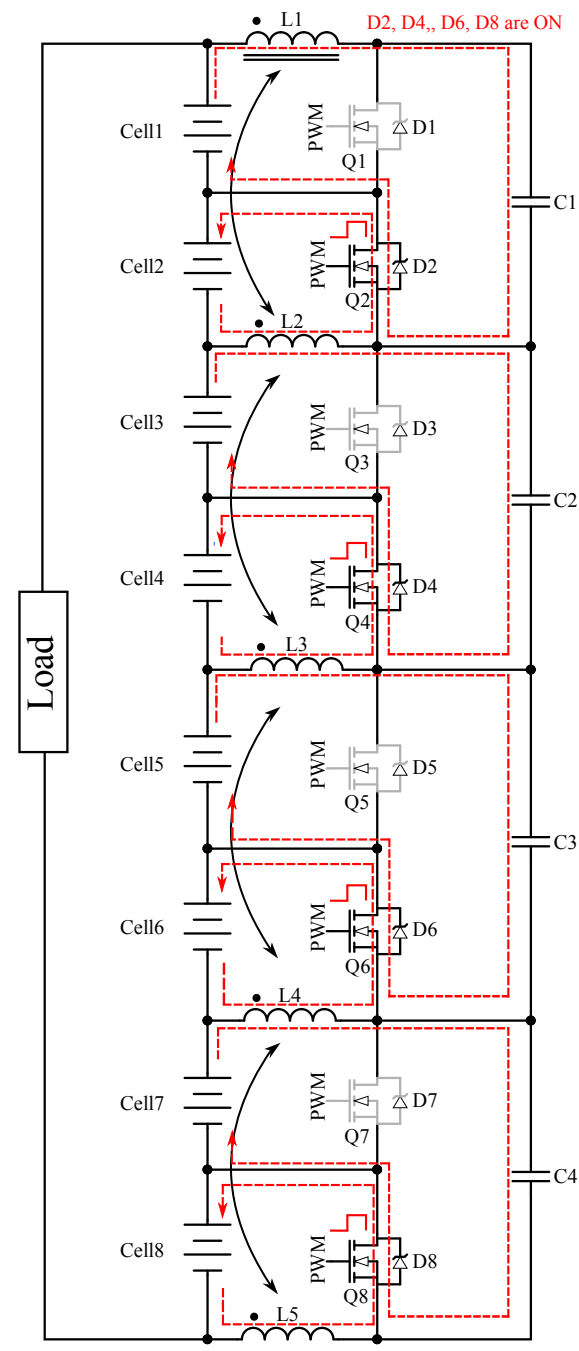

(b)

Figure 9. (a) The operational principle in the first mode; and (b) the operational principle in the second mode.

In the first mode, as shown in Figure 9a, the MOSFETs Q1, Q3, Q5, and Q7 are turned on while the other switches are turned off. The energy from even cells $\left(\operatorname{Cell}_{1,3,5,7}\right)$ is transferred to $\left(\mathrm{L}_{1,2,3,4,5}\right)$, therefore the equivalent equation can be derived as

$$
V_{\text {cell }}=L_{1} \frac{d i_{L_{1}}}{d t}+M_{12} \frac{d i_{L_{2}}}{d t}+M_{13} \frac{d i_{L_{3}}}{d t}+M_{14} \frac{d i_{L_{4}}}{d t}+M_{15} \frac{d i_{L_{5}}}{d t}
$$

where $M$ is the mutual inductance, among $\mathrm{L}_{1}, \mathrm{~L}_{2}, \mathrm{~L}_{3}$, and $\mathrm{L}_{4}$. Similarly, the cell voltage $\mathrm{V}_{\mathrm{Cell}} 2$ can be expressed as

$$
V_{\text {cell }_{2}}=-L_{2} \frac{d i_{L_{2}}}{d t}-M_{21} \frac{d i_{L_{1}}}{d t}-M_{23} \frac{d i_{L_{3}}}{d t}-M_{24} \frac{d i_{L_{4}}}{d t}-M_{25} \frac{d i_{L_{5}}}{d t}+V_{C_{1}}
$$


The cell voltage of the odd cells, $\mathrm{V}_{\text {cell }(3,5,7)}$ can be written as

$$
V_{\operatorname{cell}_{n}}=L_{k} \frac{d i_{L_{k}}}{d t}+M_{i j} \frac{d i_{L_{j}}}{d t}+M_{i j} \frac{d i_{L_{j}}}{d t}+M_{i j} \frac{d i_{L_{j}}}{d t}+M_{i j} \frac{d i_{L_{j}}}{d t}
$$

where $n=3,5,7 ; k=2,3,4 ; i=2,3,4 ; j=1,2,3,4,5$; and $i \neq j$

Similarly as before, the cell voltage of the even cells, $\mathrm{V}_{\text {cell }(4,6,8)}$ can be written as the following equation

$$
V_{\text {cell }_{n}}=-L_{k} \frac{d i_{L_{k}}}{d t}-M_{i j} \frac{d i_{L_{j}}}{d t}-M_{i j} \frac{d i_{L_{j}}}{d t}-M_{i j} \frac{d i_{L_{j}}}{d t}-M_{i j} \frac{d i_{L_{j}}}{d t}+V_{C_{m}}
$$

where $n=4,6,8 ; k=3,4,5 ; i=3,4,5 ; j=1,2,3,4,5 ; m=2,3,4 ;$ and $i \neq j$

It can be noticed that the polarity of the inductor currents are negative for the even cells.

Therefore, the cell voltages $\left(\mathrm{Cell}_{1,3,5,7}\right)$ can be rewritten as

$$
\left[\begin{array}{l}
V_{\text {cell }_{1}} \\
V_{\text {cell }_{3}} \\
V_{\text {cell }_{5}} \\
V_{\text {cell }_{7}}
\end{array}\right]=\left[\begin{array}{ccccc}
L_{1} & M_{12} & M_{13} & M_{14} & M_{15} \\
M_{21} & L_{2} & M_{23} & M_{24} & M_{25} \\
M_{31} & M_{32} & L_{3} & M_{34} & M_{35} \\
M_{41} & M_{42} & M_{43} & L_{4} & M_{45}
\end{array}\right] \times \frac{d}{d t}\left[\begin{array}{c}
i_{L_{1}} \\
i_{L_{2}} \\
i_{L_{3}} \\
i_{L_{4}} \\
i_{L_{5}}
\end{array}\right]
$$

Similarly, the cell voltage $\left(\mathrm{Cell}_{2,4,6,8}\right)$ can be written as

$$
\left[\begin{array}{c}
V_{\text {cell }_{2}} \\
V_{\text {cell }_{4}} \\
V_{\text {cell }_{6}} \\
V_{\text {cell }_{8}}
\end{array}\right]=\left[\begin{array}{ccccc}
M_{21} & L_{2} & M_{23} & M_{24} & M_{25} \\
M_{31} & M_{32} & L_{3} & M_{34} & M_{35} \\
M_{41} & M_{42} & M_{43} & L_{4} & M_{45} \\
M_{51} & M_{52} & M_{53} & M_{54} & L_{5}
\end{array}\right] \times \frac{-d}{d t}\left[\begin{array}{c}
i_{L_{1}} \\
i_{L_{2}} \\
i_{L_{3}} \\
i_{L_{4}} \\
i_{L_{5}}
\end{array}\right]+\left[\begin{array}{c}
V_{C_{1}} \\
V_{C_{2}} \\
V_{C_{3}} \\
V_{C_{4}}
\end{array}\right]
$$

In the second mode, as shown in Figure 9b, the MOSFETs Q2, Q4, Q6, and Q8 are turned on while the other switches are turned off.

The equivalent equation for $\mathrm{V}_{\text {Cell } 2}$ can be expressed as

$$
V_{\text {cell }_{1}}=L_{1} \frac{d i_{L_{1}}}{d t}+M_{12} \frac{d i_{L_{2}}}{d t}+M_{13} \frac{d i_{L_{3}}}{d t}+M_{14} \frac{d i_{L_{4}}}{d t}+M_{15} \frac{d i_{L_{5}}}{d t}+V_{C_{1}}
$$

Similarly, the cell voltage $\mathrm{V}_{\text {Cell } 2}$ can be expressed as

$$
V_{\mathrm{cell}_{2}}=-L_{2} \frac{d i_{L_{2}}}{d t}-M_{21} \frac{d i_{L_{1}}}{d t}-M_{23} \frac{d i_{L_{3}}}{d t}-M_{24} \frac{d i_{L_{4}}}{d t}-M_{25} \frac{d i_{L_{5}}}{d t}
$$

The cell voltage $\mathrm{V}_{\text {cell }(3,5,7)}$ can be written as

$$
V_{\text {cell }_{n}}=L_{k} \frac{d i_{L_{k}}}{d t}+M_{i j} \frac{d i_{L_{j}}}{d t}+M_{i j} \frac{d i_{L_{j}}}{d t}+M_{i j} \frac{d i_{L_{j}}}{d t}+M_{i j} \frac{d i_{L_{j}}}{d t}+V_{C_{m}}
$$

where $n=3,5,7 ; k=2,3,4 ; i=2,3,4 ; j=1,2,3,4,5 ; m=2,3,4$; and $i \neq j$

Similarly, the cell voltage $\mathrm{V}_{\text {cell }(4,6,8)}$ can be written as

$$
V_{\text {cell }_{n}}=-L_{k} \frac{d i_{L_{k}}}{d t}-M_{i j} \frac{d i_{L_{j}}}{d t}-M_{i j} \frac{d i_{L_{j}}}{d t}-M_{i j} \frac{d i_{L_{j}}}{d t}-M_{i j} \frac{d i_{L_{j}}}{d t}
$$


where $n=4,6,8 ; k=3,4,5 ; i=3,4,5 ; j=1,2,3,4,5$; and $i \neq j$

Therefore, the cell voltages $\left(\right.$ Cell $\left._{1,3,5,7}\right)$ can be rewritten as

$$
\left[\begin{array}{c}
V_{\text {cell }_{1}} \\
V_{\text {cell }_{3}} \\
V_{\text {cell }_{5}} \\
V_{\text {cell }_{7}}
\end{array}\right]=\left[\begin{array}{ccccc}
L_{1} & M_{12} & M_{13} & M_{14} & M_{15} \\
M_{21} & L_{2} & M_{23} & M_{24} & M_{25} \\
M_{31} & M_{32} & L_{3} & M_{34} & M_{35} \\
M_{41} & M_{42} & M_{43} & L_{4} & M_{45}
\end{array}\right] \times \frac{d}{d t}\left[\begin{array}{c}
i_{L_{1}} \\
i_{L_{2}} \\
i_{L_{3}} \\
i_{L_{4}} \\
i_{L_{5}}
\end{array}\right]+\left[\begin{array}{c}
V_{C_{1}} \\
V_{C_{2}} \\
V_{C_{3}} \\
V_{C_{4}}
\end{array}\right]
$$

Similarly, the cell voltage $\left(\mathrm{Cell}_{2,4,6,8}\right)$ can be written as

$$
\left[\begin{array}{c}
V_{\text {cell }_{2}} \\
V_{\text {cell }_{4}} \\
V_{\text {cell }_{6}} \\
V_{\text {cell }_{8}}
\end{array}\right]=\left[\begin{array}{ccccc}
M_{21} & L_{2} & M_{23} & M_{24} & M_{25} \\
M_{31} & M_{32} & L_{3} & M_{34} & M_{35} \\
M_{41} & M_{42} & M_{43} & L_{4} & M_{45} \\
M_{51} & M_{52} & M_{53} & M_{54} & L_{5}
\end{array}\right] \times \frac{-d}{d t}\left[\begin{array}{c}
i_{L_{1}} \\
i_{L_{2}} \\
i_{L_{3}} \\
i_{L_{4}} \\
i_{L_{5}}
\end{array}\right]
$$

The average capacitor voltage values $\left(C_{1}-C_{3}\right)$ are twice the voltage of one cell. This can be explained by applying the KVL around the larger loop (through Cell 2, Q1, C1, Q3, and Cell 2) in Figure $9 \mathrm{~b}$. Therefore, the KVL equation can be written as

$$
V_{C_{1}}=V_{\text {cell }_{2}}+V_{\text {cell }_{3}}
$$

Similarly, the average capacitor voltages for $C_{2}$, and $C_{3}$ can be derived as

$$
\begin{aligned}
& V_{C_{2}}=V_{\text {cell }_{4}}+V_{\text {cell }_{5}} \\
& V_{C_{3}}=V_{\text {cell }_{6}}+V_{\text {cell }_{7}}
\end{aligned}
$$

To write the state-space equation of the proposed circuit, the capacitor currents equation should be written. Therefore, the capacitor currents $C_{1}-C_{4}$ in the first stage, when switches Q1, Q3, Q5, and Q7 are turned on, can be written as

$$
C_{1} \frac{d v_{C_{1}}}{d t}=0 \quad C_{2} \frac{d v_{C_{2}}}{d t}=0 \quad C_{3} \frac{d v_{C_{3}}}{d t}=0 \quad C_{4} \frac{d c_{C_{4}}}{d t}=-i_{L_{5}}
$$

The state-space equation in the first stage, when switches Q1, Q3, Q5, and Q7 are turned on, and the other switches are turned off, can be expressed as

$$
\left[\begin{array}{ccccccccc}
L_{1} & M_{12} & M_{13} & M_{14} & M_{15} & 0 & 0 & 0 & 0 \\
-M_{21} & -L_{2} & -M_{23} & -M_{24} & -M_{25} & 0 & 0 & 0 & 0 \\
M_{21} & L_{2} & M_{23} & M_{24} & M_{25} & 0 & 0 & 0 & 0 \\
-M_{31} & -M_{32} & -L_{3} & -M_{34} & -M_{35} & 0 & 0 & 0 & 0 \\
M_{31} & M_{32} & L_{3} & M_{34} & M_{35} & 0 & 0 & 0 & 0 \\
-M_{41} & -M_{42} & -M_{43} & L_{4} & -M_{45} & 0 & 0 & 0 & 0 \\
M_{41} & M_{42} & M_{43} & L_{4} & M_{45} & 0 & 0 & 0 & 0 \\
-M_{51} & -M_{52} & -M_{53} & -M_{54} & -L_{5} & 0 & 0 & 0 & 0 \\
0 & 0 & 0 & 0 & 0 & C 1 & 0 & 0 & 0 \\
0 & 0 & 0 & 0 & 0 & 0 & C 2 & 0 & 0 \\
0 & 0 & 0 & 0 & 0 & 0 & 0 & C 3 & 0 \\
0 & 0 & 0 & 0 & 0 & 0 & 0 & 0 & C 4
\end{array}\right] \times\left[\begin{array}{c}
i_{L_{1}} \\
\hat{i_{L_{2}}} \\
\hat{i}_{L_{3}} \\
i_{L_{4}} \\
\hat{i_{L}} \\
v \hat{C}_{1} \\
v \hat{C}_{2} \\
v \hat{C}_{3} \\
v \hat{C}_{4}
\end{array}\right]=\ldots
$$




$$
\ldots\left[\begin{array}{ccccccccc}
0 & 0 & 0 & 0 & 0 & 0 & 0 & 0 & 0 \\
0 & 0 & 0 & 0 & 0 & -1 & 0 & 0 & 0 \\
0 & 0 & 0 & 0 & 0 & 0 & 0 & 0 & 0 \\
0 & 0 & 0 & 0 & 0 & 0 & -1 & 0 & 0 \\
0 & 0 & 0 & 0 & 0 & 0 & 0 & 0 & 0 \\
0 & 0 & 0 & 0 & 0 & 0 & 0 & -1 & 0 \\
0 & 0 & 0 & 0 & 0 & 0 & 0 & 0 & 0 \\
0 & 0 & 0 & 0 & 0 & 0 & 0 & 0 & -1 \\
0 & 0 & 0 & 0 & 0 & 0 & 0 & 0 & 0 \\
0 & 0 & 0 & 0 & 0 & 0 & 0 & 0 & 0 \\
0 & 0 & 0 & 0 & 0 & 0 & 0 & 0 & 0 \\
0 & 0 & 0 & 0 & -1 & 0 & 0 & 0 & 0
\end{array}\right] \times\left[\begin{array}{c}
i_{L_{1}} \\
i_{L_{2}} \\
i_{L_{3}} \\
i_{L_{4}} \\
i_{L_{5}} \\
v_{C_{1}} \\
v_{C_{2}} \\
v_{C_{3}} \\
v_{C_{4}}
\end{array}\right]+\left[\begin{array}{c}
V_{\text {cell }_{1}} \\
V_{\text {cell }_{2}} \\
V_{\text {cell }_{3}} \\
V_{\text {cell }_{4}} \\
V_{\text {cell }_{5}} \\
V_{\text {cell }_{6}} \\
V_{\text {cell }_{7}} \\
V_{\text {cell }_{8}} \\
0 \\
0 \\
0 \\
0
\end{array}\right]
$$

The average capacitor voltage values $\left(C_{2}-C_{4}\right)$ are twice the voltage of one cell. This can be explained by applying the KVL around the larger loop (through Cell 2, Q2, C2, Q4, and Cell 2) in Figure $9 b$, Therefore, the KVL equation can be written as

$$
V_{C_{2}}=V_{\mathrm{cell}_{2}}+V_{\mathrm{cell}_{3}}
$$

Similarly, the average capacitor voltages for $C_{2}$ and $C_{3}$ can be driven as

$$
\begin{gathered}
V_{C_{3}}=V_{\text {cell }_{4}}+V_{\text {cell }_{5}} \\
V_{C_{4}}=V_{\text {cell }_{6}}+V_{\text {cell }_{7}}
\end{gathered}
$$

Similarly, the capacitor currents $C_{1}-C_{4}$ during the second stage, when switches Q2, Q4, Q6, and Q8 are turned on, can be written as

$$
C_{1} \frac{d v_{C_{1}}}{d t}=i_{L_{1}} \quad C_{2} \frac{d v_{C_{2}}}{d t}=0 \quad C_{3} \frac{d v_{C_{3}}}{d t}=0 \quad C_{4} \frac{d v_{C_{4}}}{d t}=0
$$

Correspondingly, the state-space equation in the second stage, when switches Q2, Q4, Q6, and Q8 are turned on, and the other switches are turned off, can be expressed as

$$
\left[\begin{array}{ccccccccc}
L_{1} & M_{12} & M_{13} & M_{14} & M_{15} & 0 & 0 & 0 & 0 \\
-M_{21} & -L_{2} & -M_{23} & -M_{24} & -M_{25} & 0 & 0 & 0 & 0 \\
M_{21} & L_{2} & M_{23} & M_{24} & M_{25} & 0 & 0 & 0 & 0 \\
-M_{31} & -M_{32} & -L_{3} & -M_{34} & -M_{35} & 0 & 0 & 0 & 0 \\
M_{31} & M_{32} & L_{3} & M_{34} & M_{35} & 0 & 0 & 0 & 0 \\
-M_{41} & -M_{42} & -M_{43} & L_{4} & -M_{45} & 0 & 0 & 0 & 0 \\
M_{41} & M_{42} & M_{43} & L_{4} & M_{45} & 0 & 0 & 0 & 0 \\
-M_{51} & -M_{52} & -M_{53} & -M_{54} & -L_{5} & 0 & 0 & 0 & 0 \\
0 & 0 & 0 & 0 & 0 & C 1 & 0 & 0 & 0 \\
0 & 0 & 0 & 0 & 0 & 0 & C 2 & 0 & 0 \\
0 & 0 & 0 & 0 & 0 & 0 & 0 & C 3 & 0 \\
0 & 0 & 0 & 0 & 0 & 0 & 0 & 0 & C 4
\end{array}\right] \times\left[\begin{array}{c}
i_{L_{1}} \\
\hat{i_{L_{2}}} \\
\hat{L}_{L_{3}} \\
i_{L_{4}} \\
\hat{i_{L}} \\
v \hat{C}_{1} \\
v \hat{C}_{2} \\
v \hat{C}_{3} \\
v \hat{C}_{4}
\end{array}\right]=\ldots
$$




$$
\ldots\left[\begin{array}{ccccccccc}
0 & 0 & 0 & 0 & 0 & -1 & 0 & 0 & 0 \\
0 & 0 & 0 & 0 & 0 & 0 & 0 & 0 & 0 \\
0 & 0 & 0 & 0 & 0 & 0 & -1 & 0 & 0 \\
0 & 0 & 0 & 0 & 0 & 0 & 0 & 0 & 0 \\
0 & 0 & 0 & 0 & 0 & 0 & 0 & -1 & 0 \\
0 & 0 & 0 & 0 & 0 & 0 & 0 & 0 & 0 \\
0 & 0 & 0 & 0 & 0 & 0 & 0 & 0 & -1 \\
0 & 0 & 0 & 0 & 0 & 0 & 0 & 0 & 0 \\
1 & 0 & 0 & 0 & 0 & 0 & 0 & 0 & 0 \\
0 & 0 & 0 & 0 & 0 & 0 & 0 & 0 & 0 \\
0 & 0 & 0 & 0 & 0 & 0 & 0 & 0 & 0 \\
0 & 0 & 0 & 0 & 0 & 0 & 0 & 0 & 0
\end{array}\right] \times\left[\begin{array}{c}
i_{L_{1}} \\
i_{L_{2}} \\
i_{L_{3}} \\
i_{L_{4}} \\
i_{L_{5}} \\
v_{C_{1}} \\
v_{C_{2}} \\
v_{C_{3}} \\
v_{C_{4}}
\end{array}\right]+\left[\begin{array}{c}
V_{\text {cell }_{1}} \\
V_{\text {cell }_{2}} \\
V_{\text {cell }_{3}} \\
V_{\text {cell }_{4}} \\
V_{\text {cell }_{5}} \\
V_{\text {cell }_{6}} \\
V_{\text {cell }_{7}} \\
V_{\text {cell }_{8}} \\
0 \\
0 \\
0 \\
0
\end{array}\right]
$$

\section{The Simulation Results of the Proposed Cuk Converter with Coupled Inductors and Four Cells}

The simulation results of the proposed cuk converter with coupled inductors are presented in this section. Firstly, the proposed circuit was tested with four cells in MATLAB to compare the conventional and proposed circuit. Next, the proposed ćuk balancing circuit was tested with eight cells. The switches are N-channel MOSFETs with body diodes and they are triggered by pulse width modulation (PWM), created by pulse generator with a synchronous pattern. The switching frequency is $50 \mathrm{kHz}$ with the duty ratio of $50 \%$.

As compared to the general ćuk converter circuit, which uses one switch and one diode, the proposed circuit uses two switches instead of a diode. This means less voltage drop across it and more symmetry voltages for both odd cells and even cells.

The batteries were modeled with capacitors with the value of $0.5 \mathrm{~F}$, and the initial capacitor voltages were chosen to present different voltage levels. The voltages were chosen from $3 \mathrm{~V}$ to $3.7 \mathrm{~V}$ to have different imbalanced cells.

The magnetizing inductance for the coupled inductors is $10 \mu \mathrm{H}$ and the leakage inductance of $1 \mu \mathrm{H}$. All capacitors are $100 \mu \mathrm{F}$ with no series resistance.

The simulation results of the proposed ćuk converter with coupled inductors and four cells in series are presented. The cell voltages of Cells 1-4 after balancing are shown in Figure 10a. The circuit has a faster balancing time as compared to the conventional circuit presented in the previous section and the cell voltages converge at the end.

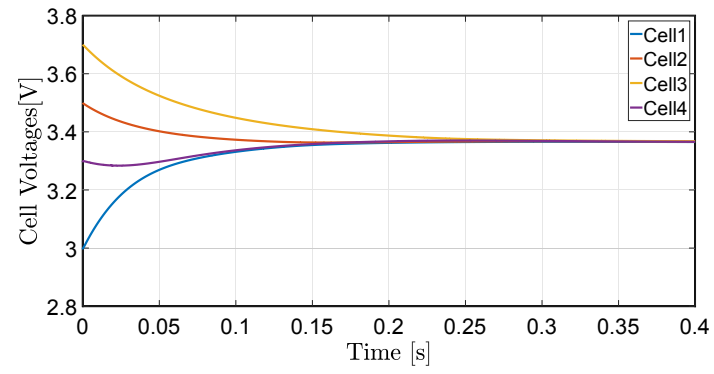

(a)

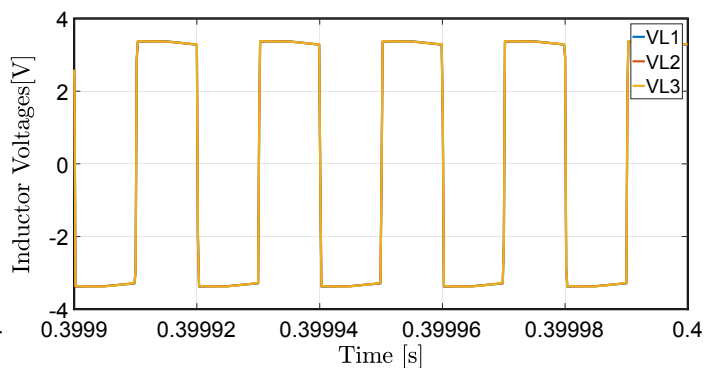

(b)

Figure 10. (a) Cell voltages of the proposed ćuk balancing circuit with four cells; and (b) inductor voltages of the proposed cuk balancing circuit with four cells in steady state.

Figure 10b shows the inductor voltages of the proposed cuk balancing circuit with four cells in steady-state. It is known that the inductor average voltage in a period in steady-state is zero. Thus, it can be seen that they are at the same levels, which means all cells are balanced, unlike in the conventional circuit, for which they are not at the same voltage levels.

In Figure 11a, the inductor currents of the proposed cuk balancing circuit with four cells in steady-state is presented. It was found that all inductor currents are the same, which means the cells 
are balanced. Figure $11 \mathrm{~b}$ shows the capacitor voltages in steady-state. It can be seen in the figure that, according to Equations (20)-(22) and (25)-(27), the average voltages across capacitors are twice the voltage of one cell.

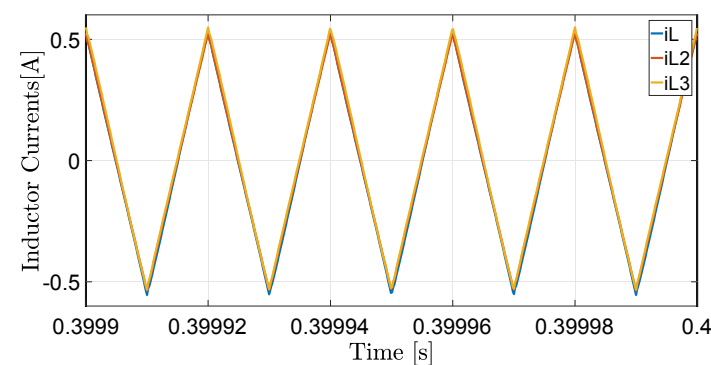

(a)

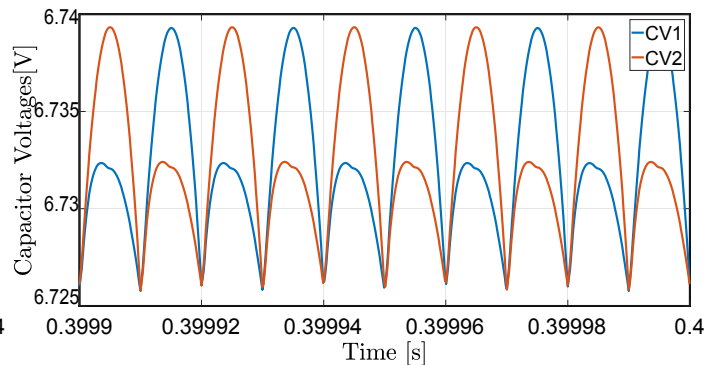

(b)

Figure 11. (a) Inductor currents of the proposed ćuk balancing circuit with four cells in steady state; and (b) capacitor voltages of the proposed ćuk balancing circuit with four cells in steady state.

\section{The Simulation Results of the Proposed Cuk Converter with Coupled Inductors and Eight Cells}

In this section, the simulation results of the proposed ćuk converter with coupled inductors are presented. Similar to the previous simulation, all parameters are the same, except the number of cells, which are increased to eight cells. The cell voltages of Cells 1-8 are shown in Figure 12a.

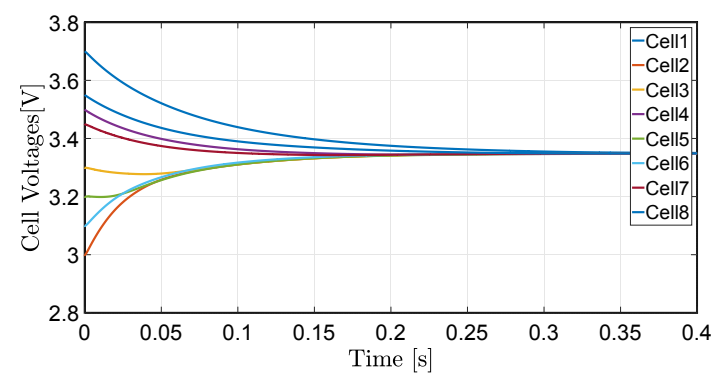

(a)

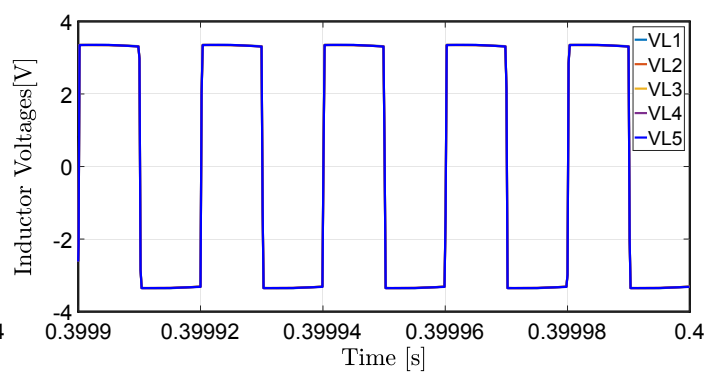

(b)

Figure 12. (a) Cell voltages of the proposed eight-cell ćuk balancing circuit; and (b) inductor voltages of the proposed ćuk balancing circuit with eight cells in steady-state.

The circuit has a faster balancing time as compared to the conventional circuit presented, and the cell voltages also converge at the end similar to the proposed circuit with four cells. As discussed above, the inductor average voltage in a period in steady-state is zero.

Similar to the previous section, it can be noticed that all inductor voltages are at the same voltage level, resulting in all cells being balanced. The inductor voltages of the proposed cuk balancing circuit with eight cells in steady-state are presented in Figure 12b.

Figure 13a shows the inductor currents of the proposed cuk balancing circuit with eight cells in transient. The figure shows that, after the balancing time is done, all inductor currents reach the same level in transient. The inductor currents of the proposed cuk balancing circuit with eight cells in steady-state, in a closer view, is presented in Figure 13b. It can be noticed that all inductor currents are the same, which means the cells are balanced.

In Figure 14a,b, the capacitor voltages in transient and steady state are presented, respectively. 


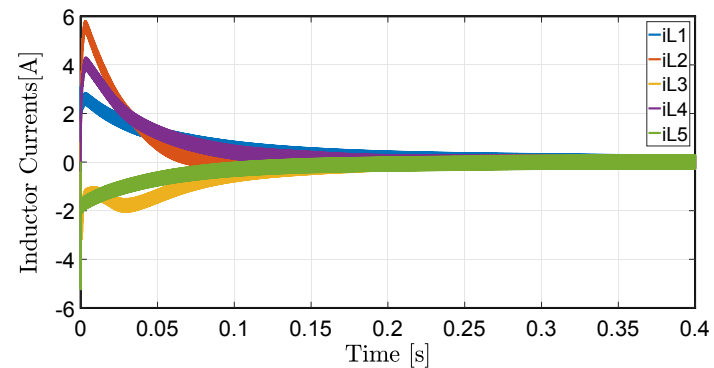

(a)

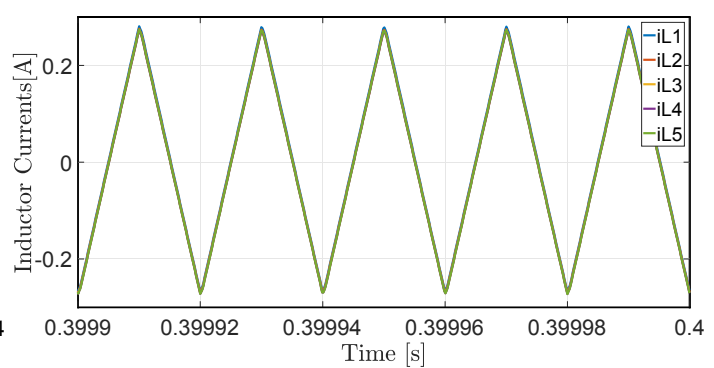

(b)

Figure 13. (a) Inductor currents of the proposed ćuk balancing circuit with eight cells; and (b) inductor currents of the proposed ćuk balancing circuit with eight cells in steady-state.

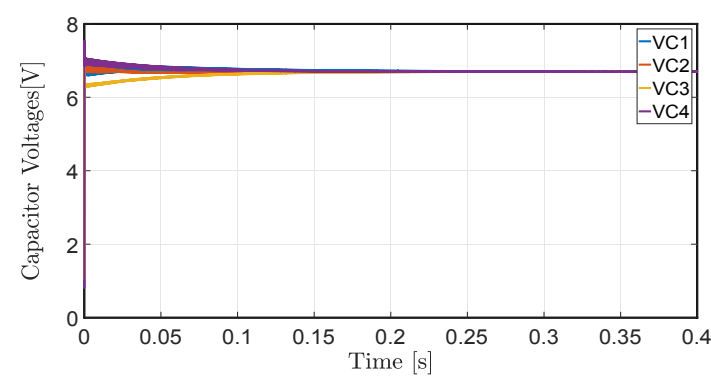

(a)

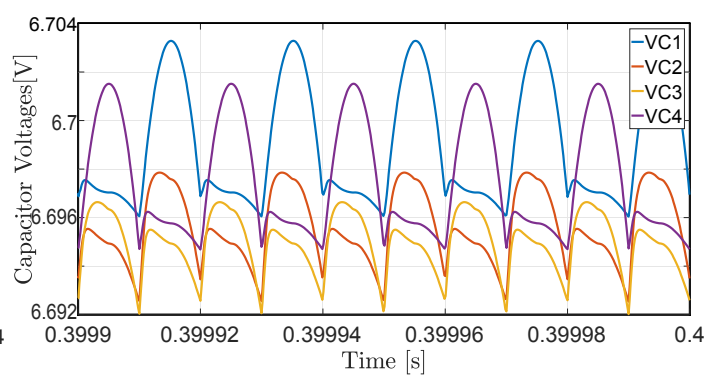

(b)

Figure 14. (a) Capacitor voltages of the proposed ćuk balancing circuit eight cells in transient; and (b) capacitor voltages of the proposed ćuk balancing circuit with eight cells in steady-state.

\section{Experimental Results}

In this section, the experimental results of the proposed ćuk converter are presented. To verify the proposed balancing circuit, a prototype of the ćuk converter balancing circuit with coupled inductors was implemented and tested with eight cells in series. The circuit equalized eight battery cells, but the number of cells can be increased or decreased depending on the desired application.

The switches are logic level N-channel MOSFETs with body diodes, and they are controlled by a pair of complementary signals in a synchronous trigger pattern generated by a micorocontroller. The N-channel MOSFETs were used to achieve the same characteristics and lower drain-source on-resistance, $\mathrm{R}_{D S(\text { on) }}$, and less voltage drop as compared to the P-channel types. MOSFETs Q1, Q3, $\mathrm{Q} 5$, and Q7 are controlled by a non-inverting MOSFET driver, which is triggered by a microcontroller, while switches Q2, Q4, Q6, and Q8 are controlled by an inverting MOSFET driver. The MOSFET characteristics are shown in Table 1.

Table 1. MOSFET characteristics.

\begin{tabular}{cc}
\hline Parameters & Values \\
\hline VDSS & $60 \mathrm{~V}$ \\
$\mathrm{R}_{\mathrm{DS} \text { (on) }}$ & $89 \mathrm{~m} \Omega$ \\
$\mathrm{I}_{\mathrm{D}}$ & $12 \mathrm{~A}$ \\
$\mathrm{~V}_{\mathrm{GS}}$ & \pm 15 \\
$\mathrm{~V}_{\mathrm{GS} \text { (th) }}$ & $1.6 \mathrm{~V}(\mathrm{~min})$ \\
$\mathrm{Q}_{\mathrm{g}}$ & $7.4 \mathrm{nC}(\mathrm{typ})$ \\
$\mathrm{t}_{\mathrm{r}}$ & $104 \mathrm{~ns}$ \\
$\mathrm{t}_{\mathrm{f}}$ & $40 \mathrm{~ns}$ \\
\hline
\end{tabular}

The proposed ćuk converter circuit contains five coupled inductors and one magnetic core with an air gap. The ferrites and coil former E 25/13/7 (EF 25) was chosen. The windings were made with five wires in one hand to obtain more symmetry in the leakage inductance of the coupled inductor winding. The magnetizing inductance of $9.89 \mu \mathrm{H}$ was obtained by tuning the air gap thickness of 
the ferrite core. The thickness of the air gap is $76 \mu \mathrm{m}$. The capacitors are $100 \mu \mathrm{F}$ multilayer ceramic capacitors in order to achieve lower equivalent series resistance (ESR).

The driver is an inverting and non-inverting MOSFET driver controlled by a microcontroller. The frequency of $48 \mathrm{kHz}$ with a duty ratio of $45 \%$ is applied to the driver. The simplified driver schematic of the proposed circuit with two cells is presented in Figure 15.

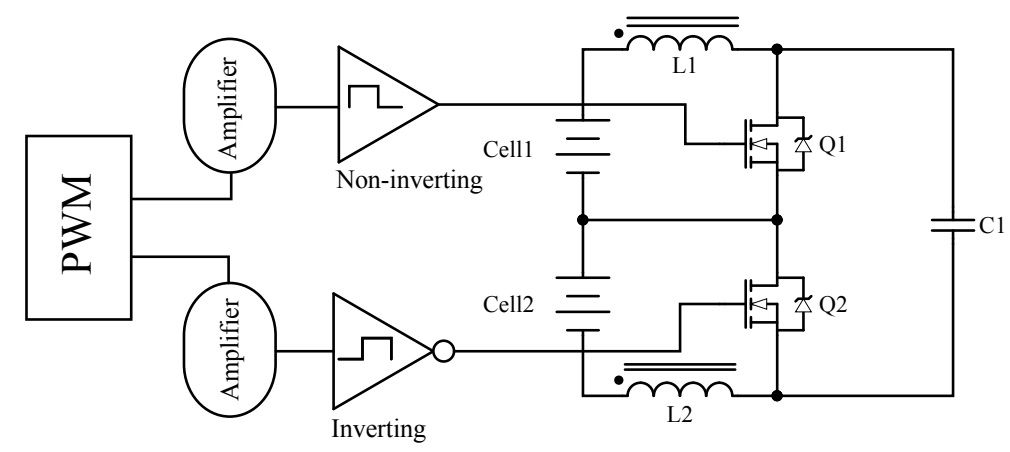

Figure 15. The control flowchart of the proposed cuk converter balancing circuit.

In the first mode, the odd MOSFETs is triggered by a non-inverting driver, which is generated by a microcontroller. Then, even MOSFETs are triggered by an inverting driver. The duty cycle of $5 \%$ is applied to the driver to avoid shoot-through between MOSFETs. The input signals to the drivers which are generated by a PWM controller are firstly amplified, and then they are applied to the drivers.

The batteries are lithium polymer battery (Lipoly) with the nominal voltage of $3.7 \mathrm{~V}$ and minimum Capacity of $1000 \mathrm{mAh}$, and they are connected in a series configuration. The cut-off discharge voltage of the battery is $3 \mathrm{~V}$ and the maximum charge voltage is $4.2 \mathrm{~V}$. The cell voltages are measured individually and the data are collected by Arduino Nano.

The gate to source voltages to the MOSFETs are generated by the microcontroller, as can be seen in Figure 16. The blue signal is applied to MOSFETs Q1, Q3, Q5, and Q7, while the reg signal is applied to MOSFETs Q2, Q4, Q6, and Q8.

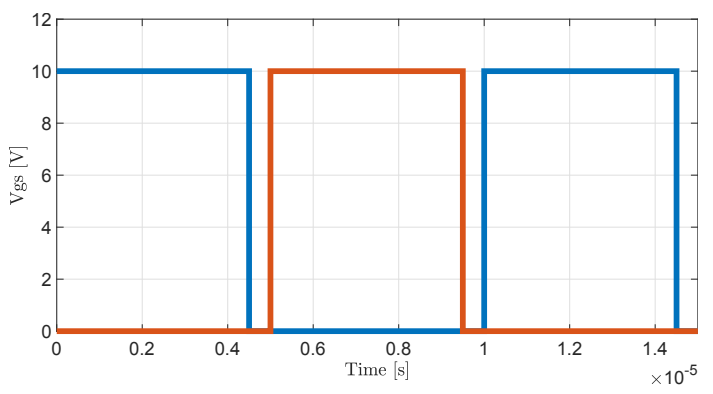

Figure 16. The gate to source voltages to the MOSFETs.

The inductor current waveforms are presented in Figure 17a. As can be noticed, the average inductor voltage is zero and all inductors have the same voltage levels, which means all cells are balanced. The capacitor voltage waveform $\mathrm{C} 1$ is presented in Figure 17b. For clarity, only the capacitor voltage waveform of one capacitor (C1) is presented.

To verify the proposed cuk balancing circuit, the circuit was tested with eight lithium-ion battery cells in a series. To have cell imbalances, the battery cells with different voltages were tested. In Figure 18a, the cell voltage waveforms of the proposed circuit is shown. The cell voltages vary from $2.9 \mathrm{~V}$ to $3.7 \mathrm{~V}$. The cell voltage waveforms with more voltage difference and one cell fully charged is shown in Figure 18b. The cell voltages vary from $2.8 \mathrm{~V}$ to $4 \mathrm{~V}$ in order to have significant voltage differences. 


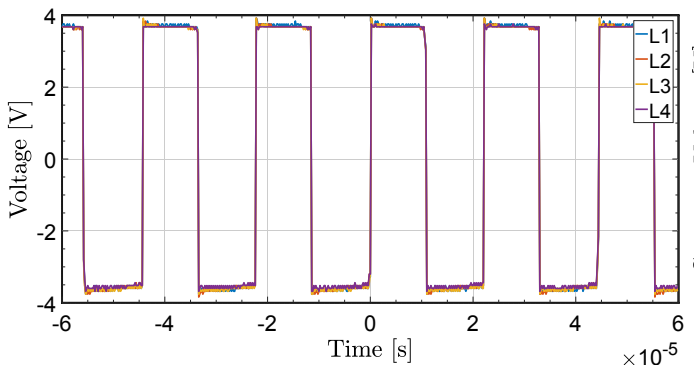

(a)

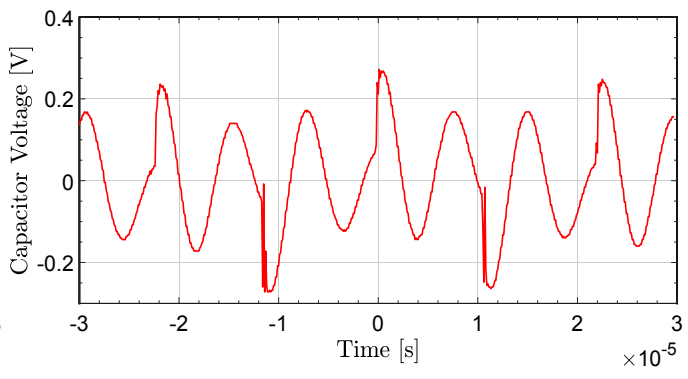

(b)

Figure 17. (a) Inductor voltage waveforms of the proposed ćuk balancing circuit; and (b) capacitor voltage waveforms of the proposed ćuk balancing circuit.

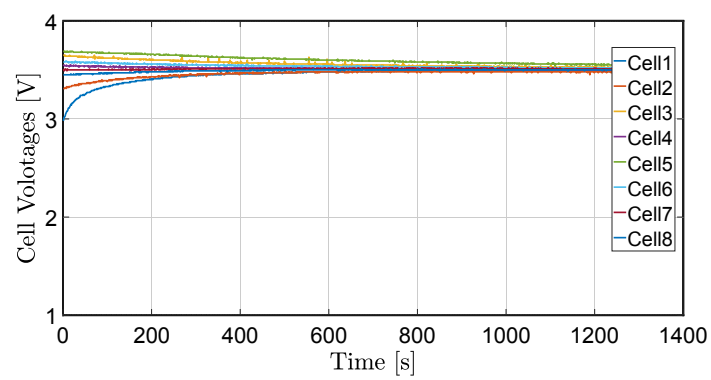

(a)

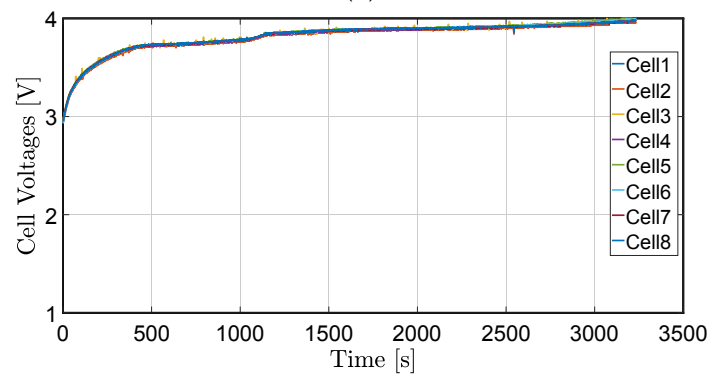

(c)

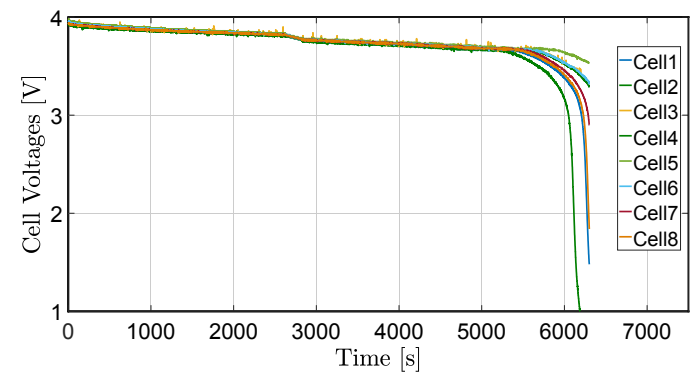

(e)

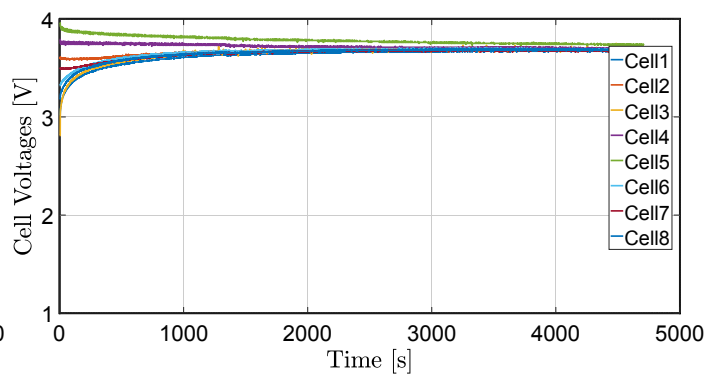

(b)

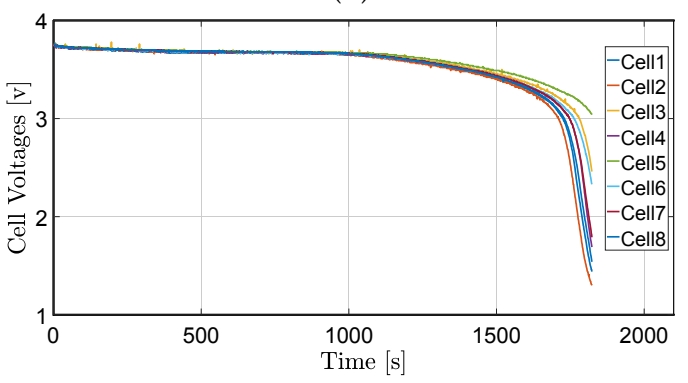

(d)

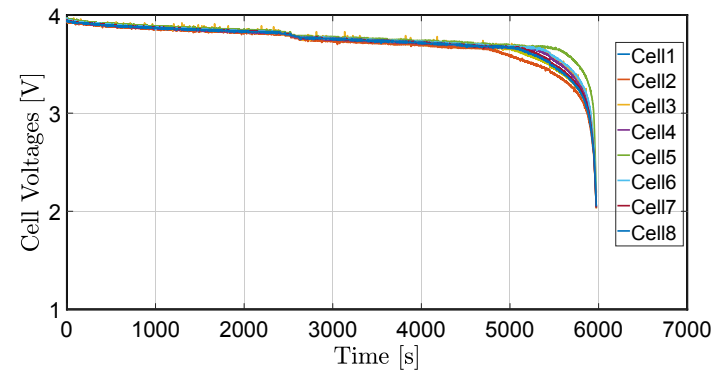

(f)

Figure 18. (a) Cell voltage waveforms of the proposed circuit after balancing; (b) cell voltage waveforms of the proposed circuit after balancing with one cell fully charged; (c) charging and equalizing voltage waveforms of the cells with balancing circuit; (d) the discharging voltage waveforms of the cells with nominal voltages without balancing circuit; (e) the discharging waveforms of the cells with fully charged cells without balancing circuit; and (f) the discharging waveforms of the cells with existing of the balancing circuit.

In Figure 18c, the charging and equalizing voltage waveforms of the proposed circuit are presented. It can be seen that all cells are charged and balanced from the beginning to the end and they are at the same voltage level. 
The discharging voltage waveforms of the cells with nominal voltages without the balancing circuit is shown in Figure 18d. It can be seen that each cell has a different discharging point, and they do not converge at the end. In Figure 18e, the discharging waveforms of the cells with fully charged cells without a balancing circuit is presented. It can be noticed that they do not converge at the end, because the balancing circuit is not presented. To verify the circuit the battery cells were discharged with the proposed circuit. The discharging waveforms of the cells with the existing balancing circuit are shown in Figure 18f.

To verify the proposed circuit, the battery cells with different voltage values were tested. The cell voltages were varied from $2 \mathrm{~V}$ to $4 \mathrm{~V}$ to apply significant voltage differences. The photograph of the experimental set up of the proposed ćuk converter balancing circuit is shown in Figure 19.

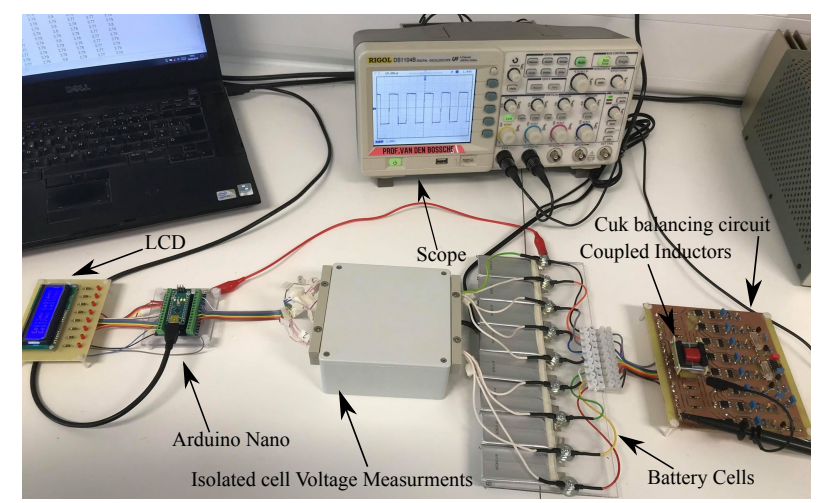

Figure 19. A photograph of the experimental set up of the proposed ćuk converter balancing circuit.

The efficiency of the proposed cuk converter balancing circuit was calculated with different loads. The loads were varied from $270 \Omega$ to $12 \Omega$, and the results are shown in Figure 20 .

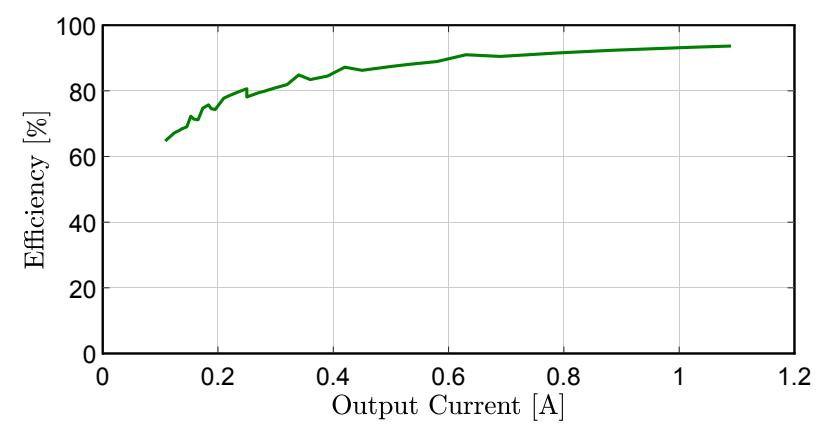

Figure 20. The efficiency of the proposed ćuk converter balancing circuit.

\section{Conclusions}

A ćuk converter balancing technique, by using a coupled inductor for lithium-ion batteries in ultra-light electric vehicles, is investigated in this paper. The proposed circuit equalizes eight li-ion battery cells in a series. The conventional ćuk converter balancing circuit requires 2(n - 1) switches in order to equalize $\mathrm{n}$ cells, but the proposed circuit requires only $\mathrm{n}$ switches for $\mathrm{n}$ cells in a battery pack. A conventional ćuk converter uses one switch and one diode, but the proposed circuit uses two MOSFETs as switch per cell, therefore, resulting in less voltage drop. Furthermore, the proposed circuit uses coupled inductors instead of un-coupled inductors, unlike the conventional type. Using coupled inductors requires fewer magnetic cores as well as windings compared to separate inductors, and the symmetry is maintained. There is always a voltage available to power the MOSFETs, even without bootstrap. The coupling permits a faster equalizing than capacitors alone. As the leakage is lower than the magnetizing, a lower impedance is created. As no separate voltage measurement is used, which is less sensitive to false readings. The gate drivers can be made in such a way that a 
virtual zero consumption is obtained at rest. The proposed circuit will equalize eight cells in a battery pack in series. The number of cells can be decreased or increased depending on the desired application. Experiments and simulations were performed to verify the feasibility of the proposed system.

Author Contributions: Conceptualization, A.F.M. and A.V.d.B.; methodology, A.F.M.; software, A.F.M.; validation, A.F.M.; formal analysis, A.F.M.; investigation, A.F.M.; resources, A.F.M.; data curation, A.F.M.; writing-original draft preparation, A.F.M.; writing - review and editing, A.F.M.; visualization, A.F.M.; and supervision, A.V.d.B.

Funding: This research received no external funding.

Conflicts of Interest: The authors declare no conflict of interest.

\section{References}

1. Gallardo-Lozano, J.; Romero-Cadaval, E.; Milanes-Montero, M.I.; Guerrero-Martinez, M.A. Battery equalization active methods. J. Power Sources 2014, 246, 934-949. [CrossRef]

2. Saxena, N.; Hussain, I.; Singh, B.; Vyas, A.L. Implementation of a Grid-Integrated PV-Battery System for Residential and Electrical Vehicle Applications. IEEE Trans. Ind. Electron. 2018, 65, 6592-6601. [CrossRef]

3. Mi, C.; Masrur, M.A. Hybrid Electric Vehicles: Principles and Applications with Practical Perspectives; John Wiley \& Sons: Hoboken, NJ, USA, 2017.

4. Emadi, A.; Lee, Y.J.; Rajashekara, K. Power Electronics and Motor Drives in Electric, Hybrid Electric, and Plug-in Hybrid Electric Vehicles. IEEE Trans. Ind. Electron. 2008, 55, 2237-2245. [CrossRef]

5. Lievre, A.; Sari, A.; Venet, P.; Hijazi, A.; Ouattara-Brigaudet, M.; Pelissier, S. Practical Online Estimation of Lithium-Ion Battery Apparent Series Resistance for Mild Hybrid Vehicles. IEEE Trans. Veh. Technol. 2016, 65, 4505-4511. [CrossRef]

6. Shang, Y.; Xia, B.; Zhang, C.; Cui, N.; Yang, J.; Mi, C. An automatic battery equalizer based on forward and flyback conversion for series-connected battery strings. In Proceedings of the 2017 IEEE Applied Power Electronics Conference and Exposition (APEC), Tampa, FL, USA, 26-30 March 2017; pp. 3218-3222.

7. Uno, M.; Tanaka, K. Single-Switch Cell Voltage Equalizer Using Multistacked Buck-Boost Converters Operating in Discontinuous Conduction Mode for Series-Connected Energy Storage Cells. IEEE Trans. Veh. Technol. 2011, 60, 3635-3645. [CrossRef]

8. Uno, M.; Tanaka, K. Accelerated Charge-Discharge Cycling Test and Cycle Life Prediction Model for Supercapacitors in Alternative Battery Applications. IEEE Trans. Ind. Electron. 2012, 59, 4704-4712. [CrossRef]

9. Hussein, A.A. Capacity fade estimation in electric vehicles Li-ion batteries using artificial neural networks. In Proceedings of the 2013 IEEE Energy Conversion Congress and Exposition, Denver, CO, USA, 15-19 September 2013; pp. 677-681.

10. Moghaddam, A.F.; Van den Bossche, A. A Cell Equalization Method Based on Resonant Switched Capacitor Balancing for Lithium Ion Batteries. In Proceedings of the 2018 9th International Conference on Mechanical and Aerospace Engineering (ICMAE), Budapest, Hungary, 10-13 July 2018; pp. 337-341.

11. Moghaddam, A.F.; Van den Bossche, A. An Active Cell Equalization Technique for Lithium Ion Batteries Based on Inductor Balancing. In Proceedings of the 2018 9th International Conference on Mechanical and Aerospace Engineering (ICMAE), Budapest, Hungary, 10-13 July 2018; pp. 274-278.

12. Moghaddam, A.F.; Van den Bossche, A. Multi-Winding Equalization Technique for Lithium Ion Batteries for Electrical Vehicles. In Proceedings of the 2018 7th International Conference on Renewable Energy Research and Applications (ICRERA), Paris, France, 14-17 October 2018; pp. 139-143.

13. Moghaddam, A.F.; Van den Bossche, A. An Efficient Equalizing Method for Lithium-Ion Batteries Based on Coupled Inductor Balancing. Electronics 2019, 8, 136. [CrossRef]

14. Moghaddam, A.F.; Van den Bossche, A. A Battery Equalization Technique Based on Ćuk Converter Balancing for Lithium Ion Batteries. In Proceedings of the 2019 8th International Conference on Modern Circuits and Systems Technologies (MOCAST), Thessaloniki, Greece, 13-15 May 2019; pp. 1-4.

15. Moghaddam, A.F.; Van den Bossche, A. Flyback Converter Balancing Technique for Lithium Based Batteries. In Proceedings of the 2019 8th International Conference on Modern Circuits and Systems Technologies (MOCAST), Thessaloniki, Greece, 13-15 May 2019; pp. 1-4. 
16. Zhang, X.; Peide, L.; Darui, W. The design and implementation of smart battery management system balance technology. J. Converg. Inf. Technol. 2011, 6, 108-116.

17. Zhi-Guo, K.; Chun-Bo, Z.; Ren-Gui, L.; Shu-Kang, C. Comparison and evaluation of charge equalization technique for series connected batteries. In Proceedings of the 2006 37th IEEE Power Electronics Specialists Conference, Jeju, Korea, 18-22 June 2006; pp. 1-6.

18. Stuart, T.A.; Zhu, W. Fast equalization for large lithium ion batteries. IEEE Aerosp. Electron. Syst. Mag. 2009, 24, 27-31. [CrossRef]

19. Lindemark, B. Individual cell voltage equalizers (ICE) for reliable battery performance. In Proceedings of the Thirteenth International Telecommunications Energy Conference-INTELEC 91, Kyoto, Japan, 5-8 November 1991; pp. 196-201.

20. Baughman, A.C.; Ferdowsi, M. Double-Tiered Switched-Capacitor Battery Charge Equalization Technique. IEEE Trans. Ind. Electron. 2008, 55, 2277-2285. [CrossRef]

21. Moo, C.S.; Hsieh, Y.C.; Tsai, I.S.; Cheng, J.C. Dynamic charge equalisation for series-connected batteries. IEEE Proc.-Electr. Power Appl. 2003, 150, 501-505. [CrossRef]

22. Imtiaz, A.M.; Khan, F.H.; Kamath, H. A low-cost time shared cell balancing technique for future lithium-ion battery storage system featuring regenerative energy distribution. In Proceedings of the 2011 Twenty-Sixth Annual IEEE Applied Power Electronics Conference and Exposition (APEC), Fort Worth, TX, USA, 6-11 March 2011; pp. 792-799.

23. Einhorn, M.; Roessler, W.; Fleig, J. Improved Performance of Serially Connected Li-Ion Batteries with Active Cell Balancing in Electric Vehicles. IEEE Trans. Veh. Technol. 2011, 60, 2448-2457. [CrossRef]

24. Moghaddam, A.F.; Van den Bossche, A. Forward Converter Current Fed Equalizer for Lithium Based Batteries in Ultralight Electrical Vehicles. Electronics 2019, 8, 408. [CrossRef]

25. Li, S.; Mi, C.C.; Zhang, M. A High-Efficiency Active Battery-Balancing Circuit Using Multiwinding Transformer. IEEE Trans. Ind. Appl. 2013, 49, 198-207. [CrossRef]

26. Lim, C.-S.; Kim, R.-Y.; Hyun, D.-S. Battery voltage sensorless charge equalizer using the multi-winding transformer. In Proceedings of the 2012 IEEE Vehicle Power and Propulsion Conference, Seoul, Korea, 9-12 October 2012; pp. 789-793.

27. Sun, J.; Lu, R.; Wei, G.; Xu, B.; Zhu, C. A high efficiency equalizer based on forward converter for series connected battery string. In Proceedings of the 2012 IEEE Vehicle Power and Propulsion Conference, Seoul, Korea, 9-12 October 2012; pp. 376-379.

28. Ouyang, Q.; Chen, J.; Xu, C.; Su, H. Cell balancing control for serially connected lithium-ion batteries. In Proceedings of the 2016 American Control Conference (ACC), Boston, MA, USA, 6-8 July 2016; pp. 3095-3100.

29. Lee, Y.S.; Duh, C.Y.; Chen, G.T.; Yang, S.C. Battery equalization using bi-directional Cuk converter in DCVM operation. In Proceedings of the 2005 IEEE 36th Power Electronics Specialists Conference, Recife, Brazil, 16 June 2005; pp. 765-771.

30. Lu, X.; Qian, W.; Peng, F.Z. Modularized buck-boost+ Cuk converter for high voltage series connected battery cells. In Proceedings of the 2012 Twenty-Seventh Annual IEEE Applied Power Electronics Conference and Exposition (APEC), Orlando, FL, USA, 5-9 Feburary 2012; pp. 2272-2278.

(C) 2019 by the authors. Licensee MDPI, Basel, Switzerland. This article is an open access article distributed under the terms and conditions of the Creative Commons Attribution (CC BY) license (http://creativecommons.org/licenses/by/4.0/). 